\title{
Audit Committee Chair Characteristics and Real Earnings Management
}

\author{
Shiyaamsundar Thiruvadi \\ Independent Consultant
}

\author{
Sheela Thiruvadi \\ Morgan State University \\ Kelly E. Carter \\ Morgan State University
}

We examine the relationship between male versus female audit committee chair characteristics and real earnings management (REM). REM occurs when the firm deviates from its normal operations because managers wish to misrepresent true performance. We find that a female audit committee chair and a chair with prior auditor experience, regardless of gender, are both associated with lower REM and thus greater financial statement transparency for investors. Overall, the findings support the ideas that (1) a female audit committee chair and (2) an older audit committee chair, regardless of gender, promote financial statement transparency.

Keywords: audit committee chair, real earnings management, gender

\section{INTRODUCTION}

We examine the relationship between male versus female audit committee chair characteristics and real earnings management (REM). REM occurs when the firm deviates from its normal operations because managers wish to misrepresent true performance (Roychowdhury 2006). Although prior studies (e.g., Visvanathan, 2008; Thiruvadi and Huang 2011) examine the effect of general audit committee characteristics on REM, no study to our knowledge examines the effect of specific characteristics of the audit committee chair on REM. This study is important because it documents new determinants of financial statement transparency, giving shareholders more confidence in their investment decisions and a more accurate picture of their wealth in a firm.

Our sample consists of 520 firm-year observations from 2009 to 2011.16 percent of the observations have a female audit committee chair. Following Roychowdhury (2006), we proxy for REM using abnormal production, abnormal discretionary expenses, and abnormal cash flow from operations (CFO). Abnormal production involves over-producing so that the per-unit cost of goods sold (CGS) is reduced, leading to abnormally higher profit. Discretionary expenses, when abnormally low, lead to abnormally high profit. Abnormally high CFO will result from (1) providing discounts to increase sales, offering very favorable credit terms, and engaging in channel-stuffing to increase sales. 
Using OLS regression, we find that a female audit committee chair and a chair with prior auditor experience, regardless of gender, are both associated with lower REM and thus greater financial statement transparency for investors. Also, the number of audit committee meetings is associated with lower REM as measured by abnormal CFO. However, audit committee chair age is positively associated with REM as measured by abnormal production. An explanation for this result is that, as a person nears retirement age, his or her concern about reputation and career is reduced (Isidro and Gonçalves, 2011). Therefore, as audit committee chair gets older, he or she is more willing to engage in REM.

Overall, the findings support the ideas that (1) a female audit committee chair and (2) an older audit committee chair, regardless of gender, promote financial statement transparency. This study adds to a growing stream of research showing that women affect corporate decision-making processes due to their distinct style of communication, participation, and work ethic (Daily and Dalton 2003). Prior research has also shown that women are more diligent, less prone to risk, and are likely to be more ethical when making decisions (Jianakoplos and Bernasek 1998; Peni and Vahama 2010; Thiruvadi and Huang 2011; Thiruvadi 2012; Sun et al. 2014; Bernile et al. 2018).

\section{LITERATURE REVIEW AND HYPOTHESIS DEVELOPMENT}

\section{Real Earnings Management}

Roychowdhury (2006) notes that REM can occur in three ways. One way is to offer price discounts to boost sales temporarily. Another way is to increase production so that the per-unit CGS is reduced. A third way is to reduce discretionary expenses so that margins are increased. After SOX, firms switched from AEM to REM because REM is more difficult to detect (Cohen et al. 2008). This behavior is consistent with Zang (2012), who finds that managers view AEM and REM as substitutes. This behavior is also consistent with agency theory (Jensen and Meckling 1976), which asserts that managers sometimes pursue their own interests rather than those of shareholders. Zang (2012) investigates the reasoning behind firms switching from AEM to REM at different intervals and finds that cost and time are key factors. Zang (2012) also finds that managers typically use REM during the fiscal year and AEM at year-end.

Graham et al. (2005) survey 421 financial executives regarding their earnings management practices. 80 percent of the respondents indicated that they would reduce discretionary spending on research and development (R\&D), advertising, and maintenance to meet earnings expectations. 55 percent of participants indicated that they would refrain from breaking ground on a new project if doing so meant that the firm would meet its earnings target even if firm value is not maximized.

Cohen and Zarowin (2010) find that firms are involved in AEM and REM around seasoned equity offerings, especially after SOX. Kim and Park (2014) find a positive association between managerial opportunism, as proxied by REM, and an auditor's resignation. Commerford et al. (2016) find that auditors are uncomfortable when managers engage in REM to meet short-term earnings benchmarks. They find that auditors address this discomfort by having discussions with clients, revising audit procedures and risk evaluation behaviors, adopting a skeptical attitude, or even resigning from an engagement. Not surprisingly, Greiner et al. (2017) find a positive relationship between aggressive REM and audit fees.

\section{Importance of Audit Committees}

According to SEC (2003a), the audit committee "plays a critical role in providing oversight over and serving as a check and balance on a company's financial reporting system". The SEC has adopted rules related to audit committee composition and function (SEC 1999a, 1999b, 2003a, 2003b). For instance, SOX requires the audit committee to be 100 percent independent to reduce the chance of fraud because independent audit committee members cannot easily bypass the firm's internal controls. Karamanou and Vafeas (2005) show that effective audit committees are associated with more accurate forecasts.

The audit committee helps to ensure the integrity of a firm's financial statements and is expected to mitigate earnings management (SEC 1999a, 1999b). Lin et al. (2009) find that audit committee independence, expertise, and size are related to lower AEM. Kalbers and Fogarty (1993) state that the internal and external audit functions consider the audit committee as a governmental authority when the 
audit committee is large. DeFond and Francis (2005) show that the size of the audit committee is directly related to the probability of boards' allocating more resources to promote financial statement quality.

Ittonen et al. (2010) find audit fees to be lower when there is a female chair. Sun et al. (2014) examine the association between independent audit committee characteristics (e.g., accounting financial expert, tenure of the board, audit committee size) and REM. They find that REM through over-production is constrained when audit committees have a financial expert or long tenure.

The Blue Ribbon Committee (1999) states that regular meetings make the audit committee efficient in discharging its duties and responsibilities. Raghunandan and Rama (2007) find that firms tend to have more audit committee meetings when the audit committee is large, when the firm is in a litigious industry, and when the overall board of directors has more meetings. Thiruvadi (2012) finds that audit committees meet more often when the committee is large and when it has a female director.

\section{Gender Differences}

Gender differences exist with respect to diligence, aggressiveness, communication style, decisionmaking ability, trust-building approach, leadership quality, risk approach behavior, and conservative outlook (Powell and Ansic, 1997; Burke and Mattis 2000; Daily and Dalton 2003; Erhardt et al. 2003; Huse et al. 2006; Adams and Ferreira 2009; Thiruvadi and Huang 2011; Thiruvadi 2012; White 2014, Francis et al. 2015; Bernile et al. 2018). Further, the under-representation of women on boards, particularly in leadership roles, has drawn the attention of regulators and legislators (e.g., Burke and Mattis 2000; White 2014; Posner 2014). To address this issue, Finland has launched a "Gender Equality" project and has instructed the media to investigate male versus female representation (Mannila 2017). Norway has also taken initiatives to address gender equality by mandating quotas and affirmative-action programs. Norway requires 40 percent of board seats to be occupied by women, and Sweden's Democratic Party recommends 25 percent (Hymowitz 2003; Casey et al. 2011). Singh et al. (2001) find that large FTSE 100 firms with high turnover and profit have more female directors. Adams and Ferreira (2004) find that the number of women on boards is associated with less variability in stock returns. Erhardt et al. (2003) find a positive relationship between gender diversity and financial performance. Carter et al. (2003) find a positive association between female or minority directors and firm value.

Daily and Dalton (2003) argue that women's style of communication, participation, and work ethic enhance corporate boards. Farrell and Hersch (2005) document that firms that perform well tend to have women on the board. Bernardi et al. (2009) find a positive relationship between women on the board of a Fortune 500 company and the company's being part of Ethisphere Magazine's World's Most Ethical Companies list. Barua et al. (2010) find that firms have high-quality accruals when a woman is on the board. Palvia et al. (2015) find that, during the 2007-2008 financial crisis, small banks that had a female CEO or board chair were less likely to fail. Thiruvadi and Huang (2011) find that earnings management is reduced when a female director is on the audit committee. Similarly, Huang et al. (2014) examine the relationship between gender and audit fees. They find that audit fees are high in firms with a female CEO. Francis et al. (2014) find a negative relationship between a female CFO and tax aggressiveness.

\section{Audit Committee Chair Characteristics Gender}

Female directors have altered the decision-making process in firms due to their communication style, decision-making ability, trust-building approach, leadership quality, and risk-averse behavior (Powell and Ansic 1997; Burke and Mattis 2000; Daily and Dalton 2003; Erhardt et al. 2003; Huse and Grethe Solberg 2006; Adams and Ferreira 2009; Thiruvadi and Huang 2011; Thiruvadi 2012; White 2014, Francis et al. 2015; Bernile et al. 2018). Thiruvadi and Huang (2011) find a negative association between a female director on the audit committee and earnings management using AEM.

Age

Mudrack (1989) shows that there is a greater likelihood of older individuals' holding higher positions and being more socially-conscious than younger people. Ali and Zhang (2015) find a negative association 
between CEO age and abnormal discretionary expenses. Huang et al. (2012) find that there is an increase in the quality of financial reports as CEOs age. However, Dechow and Sloan (1991) state that older CEO focus on short-term performance rather than long-term firm value and profitability. Isidro and Gonçalves (2011) find that older CEOs and CEO duality are more inclined to manage earnings. A CEO nearing retirement age is less less likely to take on growth projects that have a long payback period (Gibbons and Murphy 1992).

\section{CPA License}

An audit committee member with a CPA fulfills the requirements of a financial expert as defined by the SEC. CPAs are able to identify key issues and make outstanding contributions to an audit committee due to their training (Scarpati, 2003). Similarly, Aier, et al. (2005) find that there is a lower likelihood of an accounting restatement when a CFO has a CPA.

\section{Prior Auditor Experience}

An audit committee member with prior auditor experience can make a comprehensive assessment of the accounting, auditing, and internal-control issues. This skill set enables the audit committee to understand complex audit issues and suggest changes to the external auditor regarding audit planning and approach. In addition, the audit committee member can evaluate management policies and suggest suitable alternatives, enabling the company to increase its performance.

\section{Hypotheses}

After SOX, firms switched from AEM to REM (Cohen et al. 2008). This switch not only affects firm performance but also leads to deterioration in firm value (Graham et al. 2005; Roychowdhury 2006; Zang 2012). Since research shows that women on a board are associated with positive outcomes, it is likely that firms will benefit from having a female chair of the audit committee. Therefore, we put forth the hypotheses below.

H1: There is a negative association between REM (proxied by abnormal production) and a female audit committee chair.

H2: There is a positive association between REM (proxied by abnormal discretionary expenses) and a female audit committee chair.

H3: There is a positive association between REM (proxied by abnormal CFO) and a female audit committee chair.

\section{DATA AND APPROACH}

The sample includes all non-financial firms from the S\&P 500 with a December 31 fiscal year-end from 2009 to 2011 . We exclude firms with missing values and firms that do not have the required audit committee data due to absence of proxy filings. We use a final sample of 520 firm-years (158 for 2009, 162 for 2010, and 200 for 2011) after adjusting for REM data. The financial data are from Compustat. Data about certain audit committee characteristics are from Institutional Shareholder Services (ISS). We hand-collect other audit committee data from proxy statements using SEC Edgar. We also search the biographical information to verify whether the chair has a CPA and prior auditor experience.

We use the models below to estimate the association between REM and audit committee chair characteristics.

$\mathrm{REM}=\beta_{0}+\beta_{1}$ ACCGEN $+\beta_{2}$ ACCAGE $+\beta_{3}$ ACCHasCPA $+\beta_{4}$ ACCHasPriorAudExp +

$\beta_{5}$ ACMeet $+\beta_{6}$ ACSize $+\beta_{7}$ DODDFDUM $+\beta_{8}$ Size $+\beta_{9}$ MTB $+\beta_{10}$ Leverage +

$\beta_{11}$ Litigation $+\beta_{12}$ ROA 
$\mathrm{REM}=\beta_{0}+\beta_{1} \mathrm{ACCGEN}+\beta_{2} \mathrm{ACCAGE}+\beta_{3} \mathrm{ACCHasCPA}+\beta_{4} \mathrm{ACCHasPriorAudExp}+$ $\beta_{5}$ ACMeet $+\beta_{6}$ ACSize $+\beta_{7}$ DODDFDUM $+\beta_{8}$ DODDFDUM x ACCGEN +

$\beta_{9}$ Size $+\beta_{10}$ MTB $+\beta_{11}$ Leverage $+\beta_{12}$ Litigation $+\beta_{13}$ ROA

Roychowdhury (2006) hypothesizes that REM will lead to abnormally high production costs (i.e., overproducing to decrease CGS per unit), low discretionary expenses (i.e., reporting lower discretionary expenses to increase profit margins), and low cash flow from operation (i.e., offering price discounts, giving favorable credit terms, and engaging in channel-stuffing to increase sales). ${ }^{1}$ Following Roychowdhury (2006), we proxy for REM via abnormal production costs (ABPROD), abnormal discretionary expenses (ABDISEXP), and abnormal cash flow from operations (ABCFO).

Following Roychowdhury (2006), the proxies for REM are estimated as shown below. For each REM proxy, CFO, S, and A represent cash flow from operations, sales, and total assets, respectively. Also, the subscripts $t$ and ( $t-1)$ indicate contemporaneous and lagged values, respectively. Abnormal production costs (ABPROD) costs are measured as the difference between the actual and the predicted values of PROD based on the regression below. In the model, PROD equals CGS plus the change in inventory.

$\operatorname{PROD}_{\mathrm{t}} / \mathrm{A}_{\mathrm{t}-1}=\beta_{0}+\beta_{1}\left(1 / \mathrm{A}_{\mathrm{t}-1}\right)+\gamma_{1}\left(\mathrm{~S}_{\mathrm{t}} / \mathrm{A}_{\mathrm{t}-1}\right)+\gamma_{2}\left(\Delta \mathrm{S}_{\mathrm{t}} / \mathrm{A}_{\mathrm{t}-1}\right)+\gamma_{3}\left(\Delta \mathrm{S}_{\mathrm{t}-1} / \mathrm{A}_{\mathrm{t}-1}\right)+\varepsilon_{\mathrm{t}}$

Abnormal discretionary expenses (ABDISEXP) are measured as the difference between the actual and the predicted values of DISEXP from the regression below. In the model DISEXP equals R\&D +Advertising + Selling, General and Administrative Expenses (SG\&A). Advertising and R\&D set to zero if missing but SG\&A is available.

$\operatorname{DISEXP}_{\mathrm{t}} / \mathrm{A}_{\mathrm{t}-1}=\beta_{0}+\beta_{1}\left(1 / \mathrm{A}_{\mathrm{t}-1}\right)+\gamma_{1}\left(\mathrm{~S}_{\mathrm{t}-1} / \mathrm{A}_{\mathrm{t}-1}\right)+\varepsilon_{\mathrm{t}}$

Abnormal cash flow from operations (ABCFO) is measured as the difference between the actual and the predicted values from the regression below. CFO is from Compustat.

$\mathrm{CFO}_{\mathrm{t}} / \mathrm{A}_{\mathrm{t}-1}=\beta_{0}+\beta_{1}\left(1 / \mathrm{A}_{\mathrm{t}-1}\right)+\gamma_{1}\left(\mathrm{~S}_{\mathrm{t}} / \mathrm{A}_{\mathrm{t}-1}\right)+\gamma_{2}\left(\Delta \mathrm{S}_{\mathrm{t}} / \mathrm{A}_{\mathrm{t}-1}\right)+\varepsilon_{\mathrm{t}}$

ABPROD, ABDISEXP, and ABCFO are regressed on the variables specified above. We also control for factors that could be associated with REM. We control for firm size (SIZE), measured as the logarithm of the market value of equity, because it can be difficult to detect REM in large firms due to their complexity (Roychowdury 2006). We include the market-to-book ratio of equity (MTB) as a proxy for growth because high growth sometimes indicates fraud (Loebbecke et al. 1989). Further, high-growth firms can outgrow their internal controls, paving the way for REM (Doyle et al. 2007). We control for leverage (LEV), measured as long-term debt deflated by total assets, because firms with high leverage have a tendency to manipulate earnings (Cohen et al. 2008). We also control for litigious industries as they are more likely to switch to REM if faced with a lawsuit (Zang 2012). We control for ROA, measured as net income before extraordinary items divided by lagged total assets, because of the correlation between measurement error (abnormal values from the estimated models) and performance (Roychowdhury 2006).

ACCGEN equals one if the audit committee chair is a female. DODDFDUM equals one in the DoddFrank era. DODDFDUM*ACCGEN captures the effect of a female audit committee chair in the DoddFrank era. ACCAGE is the age of the audit committee chair. ACCHasCPA equals one if the audit committee chair has a CPA. ACCHasPriorAudExp equals one if the audit committee chair has prior auditor experience. ACMeet is the number of audit committee meetings. ACSize is the number of audit committee members. Litigation equals one if a firm is in one of the following industries based Standard Industry Classification (SIC) Code: pharmaceuticals (SIC codes 2833 - 2836), computers (3570 - 3577), electronics (3600 - 3674), retail (5200 - 5961), or software (7370). 


\section{RESULTS}

TABLE 1

SAMPLE SELECTION PROCESS

\begin{tabular}{|l|c|}
\hline \multicolumn{1}{|c|}{ Item } & 2009 to 2011 \\
\hline Firms from the S\&P 500 & 1500 \\
\hline Less: Fiscal year other than Dec 31 & -533 \\
\hline Less: SIC code between 4400 and 5000 & -171 \\
\hline Less: SIC code between 6000 and 6500 & -216 \\
\hline Less: Missing data due to lack of proxy filings & -60 \\
\hline Total & 520 \\
\hline
\end{tabular}

TABLE 2

DESCRIPTIVE STATISTICS

\begin{tabular}{|c|c|c|c|c|c|}
\hline Variable & Mean & S.D & $25^{\text {th }}$ Percentile & Median & $75^{\text {th }}$ Percentile \\
\hline ABPROD & -0.03 & 0.14 & -0.12 & -0.03 & 0.05 \\
\hline ABDIS & 0.05 & 0.20 & -0.07 & 0.00 & 0.13 \\
\hline ABCFO & -0.04 & 0.12 & -0.07 & -0.02 & 0.02 \\
\hline ACCGend & 0.16 & 0.37 & 0.00 & 0.00 & 0.00 \\
\hline ACCAge & 64.24 & 6.70 & 60.00 & 65.00 & 69.00 \\
\hline ACCHasCPA & 0.32 & 0.49 & 0.00 & 0.00 & 1.00 \\
\hline ACCHasPriorAudExp & 0.31 & 0.48 & 0.00 & 0.00 & 1.00 \\
\hline ACMeet & 8.49 & 2.62 & 7.00 & 8.00 & 10.00 \\
\hline ACSize & 4.30 & 1.05 & 4.00 & 4.00 & 5.00 \\
\hline DODDFDUM & 0.38 & 0.49 & 0.00 & 0.00 & 1.00 \\
\hline DODDFDMACCGend & 0.06 & 0.24 & 0.00 & 0.00 & 0.00 \\
\hline Size & 9.52 & 1.07 & 8.72 & 9.29 & 10.20 \\
\hline MTB & 3.30 & 18.42 & 1.91 & 2.75 & 4.36 \\
\hline Leverage & 0.54 & 0.20 & 0.41 & 0.53 & 0.66 \\
\hline Litigation & 0.33 & 0.47 & 0.00 & 0.00 & 1.00 \\
\hline ROA & 0.13 & 0.40 & 0.04 & 0.08 & 0.12 \\
\hline Debt Ratio & 0.54 & 0.20 & 0.41 & 0.53 & 0.66 \\
\hline
\end{tabular}

Note: The sample includes 520 observations from non-financial firms in the S\&P 500 and Compustat.

Table 1 provides information about the sample selection process. We began with 1,500 firm-yearss, excluded 980, and ended up with 520 firm-years. Table 2 provides descriptive data about the sample. The average debt-to-asset ratio (Leverage) is 0.54, while the mean MTB is 3.30. 32.5 percent of the firms are in litigious industries. The average audit committee has 4.30 members. The mean (median) number of audit committee meetings is $8.49(8.0)$. 451 of the 520 observations have more than five meetings. Only $64(16 \%)$ of the 520 firm-years have a female as the audit committee chair. The analysis of Pearson correlations involving the explanatory variables indicates that only two of the correlations exceeds 0.30 , suggesting that multi-collinearity is not likely to be a problem. This is confirmed later by variance inflation factor (VIF) scores, none of which exceeds 3.2 . 
TABLE 3

REGRESSION RESULTS

MALE VERSUS FEMALE AUDIT COMMITTEE CHAIR CHARACTERISTICS AND REM

Dependent Variable: ABPROD

\begin{tabular}{|c|r|r|r|}
\hline Variable & \multicolumn{1}{|c|}{ Coefficient } & \multicolumn{1}{c|}{ T-stat. } & p-value \\
\hline Intercept & -0.034 & -0.397 & 0.692 \\
\hline ACCGEN & -0.010 & -0.557 & 0.578 \\
\hline ACCAGE & 0.002 & 1.632 & 0.103 \\
\hline ACCHasCPA & 0.027 & 1.244 & 0.214 \\
\hline ACCHasPriorAudExp & -0.036 & -1.618 & 0.106 \\
\hline ACMeet & 0.002 & 0.908 & 0.364 \\
\hline ACSize & 0.006 & 1.027 & 0.305 \\
\hline DODDFDUM & 0.024 & 1.907 & 0.057 \\
\hline Size & -0.016 & -2.615 & 0.009 \\
\hline MTB & 0.000 & -1.060 & 0.290 \\
\hline Leverage & 0.032 & 1.025 & 0.306 \\
\hline Litigation & -0.029 & -2.172 & 0.030 \\
\hline ROA & -0.016 & -1.042 & 0.298 \\
\hline
\end{tabular}

$\mathrm{N}=520$

F.Stat $=3.00$

$\mathrm{P}<.001$;

$\operatorname{Adj} . R^{2}=.044$

Table 3 presents the results of regressions where REM is measured as ABPROD. The positive and marginally-significant (at the 10.3-percent level) coefficient on ACCAGE indicates that, as a chair (whether male or female) gets older, he or she is more likely to be associated with REM by producing more to reduce CGS. This result can be explained by the view that, as a chair gets older, he or she is less concerned about reputational damage or career prospects (Isidro and Gonçalves 2011). ACCGEN and ACSize do not affect ABPROD, but firm size does, as larger firms are associated with lower ABPROD.

\section{TABLE 4 \\ REGRESSION RESULTS \\ MALE VERSUS FEMALE AUDIT COMMITTEE CHAIR CHARACTERISTICS AND REM}

Dependent Variable: ABDISEXP

\begin{tabular}{|c|c|c|c|}
\hline Variable & Coefficient & T-stat. & p-value \\
\hline Intercept & -0.26 & -2.03 & 0.04 \\
\hline ACCGEN & 0.04 & 1.71 & 0.09 \\
\hline ACCAGE & 0.00 & 0.26 & 0.80 \\
\hline ACCHasCPA & -0.03 & -0.98 & 0.33 \\
\hline ACCHasPriorAudExp & 0.05 & 1.67 & 0.10 \\
\hline ACMeet & 0.00 & -0.17 & 0.87 \\
\hline ACSize & 0.01 & 0.82 & 0.41 \\
\hline DODDFDUM & -0.04 & -1.97 & 0.05 \\
\hline Size & 0.02 & 2.60 & 0.01 \\
\hline MTB & 0.00 & 0.75 & 0.45 \\
\hline
\end{tabular}




\begin{tabular}{|c|c|c|c|}
\hline Leverage & 0.01 & 0.32 & 0.75 \\
\hline Litigation & 0.08 & 4.18 & 0.00 \\
\hline ROA & 0.02 & 1.08 & 0.28 \\
\hline
\end{tabular}

$\mathrm{N}=520$;

F.Stat $=3.81$

$\mathrm{P}<.001 ;$

Adj. $\mathrm{R}^{2}=.061$

Table 4 presents the results of regressions where REM is measured as ABDISEXP. The coefficient of ACCGEN is positive, indicating that a female audit committee chair is associated with higher ABDISEXP and thus lower REM. Roychowdhury (2006) argues that a firm can report higher income by reducing its discretionary expendtiures of $\mathrm{R} \& \mathrm{D}$, advertising, and SG\&A. The positive coefficient of ACCGEN thus indicates that a female audit committee chair increases ABDISEXP, reducing REM. Similarly, the positive coefficient of ACCHasPriorAudExp is positive, indicating that a chair's (male's or female's) auditing experience is associated with lower REM.

TABLE 5

REGRESSION RESULTS

MALE VERSUS FEMALE AUDIT COMMITTEE CHAIR CHARACTERISTICS AND REM

\begin{tabular}{|c|c|c|c|}
\hline \multicolumn{1}{|c|}{ Dependent Variable: ABCFO } \\
\hline Variable & Coefficient & T-stat. & p-value \\
\hline Intercept & -0.16 & -2.17 & 0.03 \\
\hline ACCGEN & 0.03 & 2.00 & 0.05 \\
\hline ACCAGE & 0.00 & 1.57 & 0.12 \\
\hline ACCHasCPA & -0.01 & -0.31 & 0.76 \\
\hline ACCHasPriorAudExp & -0.02 & -0.91 & 0.37 \\
\hline ACMeet & 0.00 & 2.03 & 0.04 \\
\hline ACSize & 0.00 & 0.70 & 0.48 \\
\hline DODDFDUM & 0.03 & 2.66 & 0.01 \\
\hline Size & -0.01 & -1.09 & 0.28 \\
\hline MTB & 0.00 & 0.27 & 0.79 \\
\hline Leverage & 0.09 & 3.47 & 0.00 \\
\hline Litigation & -0.04 & -3.71 & 0.00 \\
\hline ROA & 0.00 & -0.08 & 0.94 \\
\hline
\end{tabular}

$\mathrm{N}=520$

F.Stat $=5.00$

$\mathrm{P}<.001$

Adj. $R^{2}=.085$

Table 5 presents the results of regressions where REM is measured as ABCFO. The positive coefficient on ACCGEN indicates that a female audit committee chair is associated with higher ABCFO and thus lower REM. Roychowdhury (2006) argues that a firm can report higher income by increasing sales via lenient credit terms, channel-stuffing, and price discounts. It follows that higher levels of ABCFO will reduce income. 
TABLE 6

REGRESSION RESULTS WITH ACCGEN X DODDFDUM MALE VERSUS FEMALE AUDIT COMMITTEE CHAIR CHARACTERISTICS AND REM

Dependent Variable: ABPROD

\begin{tabular}{|c|c|c|c|}
\hline Variable & Coefficient & T-stat. & p-value \\
\hline Intercept & -0.03 & -0.39 & 0.70 \\
\hline ACCGEN & -0.02 & -0.76 & 0.45 \\
\hline ACCAGE & 0.00 & 1.64 & 0.10 \\
\hline ACCHasCPA & 0.03 & 1.26 & 0.21 \\
\hline ACCHasPriorAudExp & -0.04 & -1.64 & 0.10 \\
\hline ACMeet & 0.00 & 0.91 & 0.36 \\
\hline ACSize & 0.01 & 1.02 & 0.31 \\
\hline DODDFDUM & 0.02 & 1.54 & 0.12 \\
\hline ACCGEN X DODDFDUM & 0.02 & 0.54 & 0.59 \\
\hline Size & -0.02 & -2.62 & 0.01 \\
\hline MTB & 0.00 & -1.07 & 0.28 \\
\hline Leverage & 0.03 & 1.01 & 0.31 \\
\hline Litigation & -0.03 & -2.10 & 0.04 \\
\hline ROA & -0.02 & -1.02 & 0.31 \\
\hline
\end{tabular}

$\mathrm{N}=520$;

F.Stat $=2.78$

$\mathrm{P}<.001$;

Adj. $\mathrm{R}^{2}=.043$

TABLE 7

REGRESSION RESULTS WITH ACCGEN X DODDFDUM

MALE VERSUS FEMALE AUDIT COMMITTEE CHAIR CHARACTERISTICS AND REM

Dependent Variable: ABDISEXP

\begin{tabular}{|c|c|c|c|}
\hline & Coefficient & T-stat. & p-value \\
\hline Variable & -0.26 & -2.01 & 0.04 \\
\hline Intercept & 0.03 & 0.83 & 0.41 \\
\hline ACCGEN & 0.00 & 0.28 & 0.78 \\
\hline ACCAGE & -0.03 & -0.94 & 0.35 \\
\hline ACCHasCPA & 0.05 & 1.61 & 0.11 \\
\hline ACCHasPriorAudExp & 0.00 & -0.17 & 0.87 \\
\hline ACMeet & 0.01 & 0.81 & 0.42 \\
\hline ACSize & -0.04 & -2.20 & 0.03 \\
\hline DODDFDUM & 0.05 & 0.98 & 0.33 \\
\hline ACCGEN X DODDFDUM & 0.02 & 2.58 & 0.01 \\
\hline Size & 0.00 & 0.72 & 0.47 \\
\hline MTB & 0.01 & 0.30 & 0.76 \\
\hline Leverage & 0.09 & 4.25 & 0.00 \\
\hline Litigation & 0.03 & 1.11 & 0.27 \\
\hline ROA & & & \\
\hline
\end{tabular}

$\mathrm{N}=520$

F.Stat $=3.59$

$\mathrm{P}<.001$;

Adj. $R^{2}=.061$ 
TABLE 8

REGRESSION RESULTS REGRESSION RESULTS WITH ACCGEN X DODDFDUM MALE VERSUS FEMALE AUDIT COMMITTEE CHAIR CHARACTERISTICS AND REM

Dependent Variable: ABCFO
\begin{tabular}{|c|c|c|c|}
\hline Variable & Coefficient & T-stat. & p-value \\
\hline Intercept & -0.16 & -2.18 & 0.03 \\
\hline ACCGEN & 0.04 & 1.95 & 0.05 \\
\hline ACCAGE & 0.00 & 1.56 & 0.12 \\
\hline ACCHasCPA & -0.01 & -0.33 & 0.74 \\
\hline ACCHasPriorAudExp & -0.02 & -0.88 & 0.38 \\
\hline ACMeet & 0.00 & 2.03 & 0.04 \\
\hline ACSize & 0.00 & 0.71 & 0.48 \\
\hline DODDFDUM & 0.03 & 2.66 & 0.01 \\
\hline ACCGEN X DODDFDUM & -0.02 & -0.55 & 0.58 \\
\hline Size & -0.01 & -1.08 & 0.28 \\
\hline MTB & 0.00 & 0.29 & 0.77 \\
\hline Leverage & 0.09 & 3.47 & 0.00 \\
\hline Litigation & -0.04 & -3.74 & 0.00 \\
\hline ROA & 0.00 & -0.10 & 0.92 \\
\hline
\end{tabular}

$\mathrm{N}=520$

F.Stat $=4.63$

$\mathrm{P}<.001$;

Adj. $R^{2}=.084$

Tables 6, 7, and 8 present the results of regressions where DODDFDUM is interacted with ACCGEN to measure the effect of a female chair on REM in the Dodd-Frank era. All three Tables show that no difference in REM exists when a female chairs the audit committee in the Dodd-Frank era. However, DODDFDUM is typically positive in Tables 7 and 8, where REM is measured as ABDISEXP and ABCFO, respectively. The standalone gender variable ACCGEN is positive in Table 8.

\section{CONCLUSION}

In recent years, scrutiny of the audit committee has increased, especially after SOX, due to its oversight role in the integrity of the financial statement. Moreover, managers have switched from AEM to REM postSOX because REM is more difficult to detect (Cohen at al. 2008). Per Roychowdhury (2006), we proxy for REM via abnormal production costs, abnormal discretionary expenses, and abnormal CFO.

Further, the under-representation of women in corporate boards, particularly in leadership positions, has caught the attention of legislators, regulators, and the public (e.g., Burke and Mattis 2000; White 2014; Posner 2014; Mannila 2017; Kaplan and Sorensen 2017; Bernile et al. 2108). To address this issue, Finland has commissioned a "Gender Equality" project and has asked the media to examine the way that they represent men versus women (Mannila 2017).

We examine the association between the presence of male versus female audit committee chairs and REM using 520 firm-years from the S\&P 500 from 2009 to 2011. Our main result is that audit committees that have a female chair and a chair (regardless of gender) with prior auditor experience constrain REM. Since our paper uses only U.S. data, the results might not generalize to the rest of the world. Conducting a similar study using global data is an interesting avenue for future research. 


\section{ENDNOTE}

1. We refer interested readers to Roychowdhury (2006) for the rationale for including the REM proxies in the model.

\section{REFERENCES}

Abbott, L.J., Parker, S., Peters, G.F., \& Raghunandan, K. (2003). The association between audit committee characteristics and audit fees. Auditing: A Journal of Practice \& Theory, 22(2), 17-32.

Adams, R., \& Ferreira, D. (2004). Diversity and incentives in teams: Evidence from corporate boards. Unpublished working paper.

Aier, J.K., Comprix, J., Gunlock, M.T., \& Lee, D. (2005). The financial expertise of CFOs and accounting restatements. Accounting Horizons, 19(3), 123-135.

Ali, A., \& Zhang, W. (2015). CEO tenure and earnings management. Journal of Accounting and Economics, 59(1), 60-79.

Barua, A., Davidson, L.F., Rama, D.V., \& Thiruvadi, S. (2010). CFO gender and accruals quality. Accounting Horizons, 24(1), 25-39.

Bernardi, R.A., Bosco, S.M., \& Columb, V.L. (2009). Does female representation on boards of directors associate with the 'most ethical companies' list? Corporate Reputation Review, 12(3), 270-280.

Blue Ribbon Committee (BRC). (1999). Report and Recommendations of the Blue Ribbon Committee on Improving the Effectiveness of Corporate Audit Committees. New York: NYSE.

Burke, R., \& Mattis, M. (2000). Women on corporate boards of directors: Where do we go from here? In R.J. Burke \& M.C. Mattis (Eds.), Women on Corporate Boards of Directors (pp. 3-10). Amsterdam: Kluwer Academic Publishers.

Burke, R.J. (2000). Women on Canadian corporate boards of directors: Still a long way to go. In R.J. Burke \& M.C. Mattis (Eds.), Women on Corporate Boards of Directors (pp. 97-109). Dordrecht: Springer.

Carter, D.A., Simkins, B.J., \& Simpson, W.G. (2003). Corporate governance, board diversity, and firm value. Financial Review, 38(1), 33-53.

Casey, C., Skibnes, R., \& Pringle, J.K. (2011). Gender equality and corporate governance: Policy strategies in Norway and New Zealand. Gender, Work \& Organization, 18(6), 613-630.

Cohen, D.A., \& Zarowin, P. (2010). Accrual-based and REM activities around seasoned equity offerings. Journal of Accounting and Economics, 50(1), 2-19.

Cohen, D.A., Dey, A., \& Lys, T.Z. (2008). Real and accrual-based earnings management in the pre-and post-Sarbanes-Oxley periods. Accounting Review, 83(3), 757-787.

Commerford, B.P., Hermanson, D.R., Houston, R.W., \& Peters, M.F. (2016). REM: A threat to auditor comfort? Auditing: A Journal of Practice \& Theory, 35(4), 39-56.

Daily, C.M., \& Dalton, D.R. (2003). Women in the boardroom: A business imperative. Journal of Business Strategy, 24(5).

Dechow, P.M., \& Sloan, R.G. (1991). Executive incentives and the horizon problem: An empirical investigation. Journal of Accounting and Economics, 14(1), 51-89.

Doyle, J., Ge, W., \& McVay, S. (2007). Determinants of weaknesses in internal control over financial reporting. Journal of Accounting and Economics, 44(1-2), 193-223.

Erhardt, N.L., Werbel, J.D., \& Shrader, C.B. (2003). Board of director diversity and firm financial performance. Corporate Governance: An International Review, 11(2), 102-111.

Farrell, K.A., \& Hersch, P.L. (2005). Additions to corporate boards: the effect of gender. Journal of Corporate Finance, 11(1-2), 85-106.

Francis, B.B., Hasan, I., Wu, Q., \& Yan, M. (2014). Are female CFOs less tax aggressive? Evidence from tax aggressiveness. The Journal of the American Taxation Association, 36(2), 171-202.

Gibbons, R., \& Murphy, K. (1992). Does executive compensation affect investment? NBER Working Paper No. w4135. Retrieved from https://ssrn.com/abstract $=981138$ 
Graham, J.R., Harvey, C.R., \& Rajgopal, S. (2005). The economic implications of corporate financial reporting. Journal of Accounting and Economics, 40(1-3), 3-73.

Greiner, A., Kohlbeck, M.J., \& Smith, T.J. (2017). The relationship between aggressive REM and current and future audit fees. Auditing: A Journal of Practice \& Theory, 36(1), 85-107.

Huang, H.W., Rose-Green, E., \& Lee, C.C. (2012). CEO age and financial reporting quality. Accounting Horizons, 26(4), 725.

Huang, T.C., Huang, H.W., \& Lee, C.C. (2014). Corporate executive's gender and audit fees. Managerial Auditing Journal, 29(6), 527-547.

Huse, M., \& Grethe Solberg, A. (2006). Gender-related boardroom dynamics: How Scandinavian women make and can make contributions on corporate boards. Women in Management Review, 21(2), $113-130$.

Hymowitz, C. (2003). In the lead: In the US, what will it take to create diverse boardrooms. Wall Street Journal, 8, B1.

Isidro, H., \& Gonçalves, L. (2011). Earnings management and CEO characteristics in Portuguese firms. Corporate Ownership and Control, (1), 87-95.

Ittonen, K., Miettinen, J., \& Vähämaa, S. (2010). Does female representation on audit committees affect audit fees? Quarterly Journal of Finance and Accounting, pp. 113-139.

Jensen, M.C., \& Meckling, W.H. (1976). Theory of the firm: Managerial behavior, agency costs and ownership structure. Journal of Financial Economics, 3(4), 305-360.

Jianakoplos, N.A., \& Bernasek, A. (1998). Are women more risk averse? Economic Inquiry, 36(4), 620630.

Kalbers, L.P., \& Fogarty, T.J. (1993). Audit committee effectiveness: An empirical investigation of the contribution of power. Auditing: A Journal of Practice \& Theory, 12(1), 24-29.

Karamanou, I., \& Vafeas, N. (2005). The association between corporate boards, audit committees, and management earnings forecasts: An empirical analysis. Journal of Accounting Research, 43(3), 453-486.

Kim, Y., \& Park, M.S. (2014). Real activities manipulation and auditors' client-retention decisions. Accounting Review, 89(1), 367-401.

Levitt, A. (1998, September 28). The numbers game. Remarks delivered at the NYU Center for Law and Business. New York, NY. Retrieved from http://www.sec.gov/news/speech/speecharchive/1998/spch220.txt

Lin, P.T., Hutchinson, M.R., \& Percy, M. (2009). The role of the audit committee and institutional investors in constraining earnings management: evidence from Chinese firms listed in Hong Kong. In Proceedings of Accounting \& Finance Association of Australia \& New Zealand Annual Conference 2009. Accounting and Finance Association of Australia and New Zealand (AFAANZ).

Loebbecke, J.K., Eining, M.M., \& Willingham, J.J. (1989). Auditors experience with material irregularities-frequency, nature, and detectability. Auditing: A Journal of Practice \& Theory, 9(1), $1-28$.

Mannila, S. (2017). Women and men in the news: Report on gender representation in Nordic news content and the Nordic media industry. Nordic Council of Ministers.

Mudrack, P.E. (1989). Age-related differences in Machiavellianism in an adult sample. Psychological Reports, 64(3_suppl), 1047-1050.

Palvia, A., Vähämaa, E., \& Vähämaa, S. (2013, June). Do Female CEOs and Chairwomen Constrain Bank Risk-Taking? Evidence from the Financial Crisis. Working Paper in 25th Australasian Finance and Banking Conference. SSRN.

Peni, E., \& Vähämaa, S. (2010). Female executives and earnings management. Managerial Finance, $36(7), 629-645$.

Posner, C. (2014). More Women on Boards: It's the economy, stupid. Retrieved from https://cooleypubco.com/2014/09/18/more-women-on-boards-its-the-economy-stupid/ 
Powell, M., \& Ansic, D. (1997). Gender differences in risk behaviour in financial decision-making: An experimental analysis. Journal of Economic Psychology, 18(6), 605-628.

Raghunandan, K., \& Rama, D.V. (2007). Determinants of audit committee diligence. Accounting Horizons, 21(3), 265-279.

Roychowdhury, S. (2006). Earnings management through real activities manipulation. Journal of Accounting and Economics, 42(3), 335-370.

Scarpati, S.A. (2003). CPAs as Audit Committee Members: Be Part of the New Vanguard in Corporate Governance. Journal of Accountancy, 196(3), 32.

Securities and Exchange Commission. (1999a). Audit Committee Disclosure. Release No. 34-42266. Washington, DC: SEC.

Securities and Exchange Commission. (1999b). NYSE Rulemaking. Release No. 34-42233; File No. SRNYSE-99-39. Washington, DC: SEC.

Securities and Exchange Commission. (2003). Disclosure Required by Sections 406 and 407 of the Sarbanes-Oxley Act of 2002. Retrieved from https://www.sec.gov/rules/final/33-8177.htm

Securities and Exchange Commission. (2003a). Release Nos. 33-8330; 34-47654. Final Rule: Standards Related to Listed Company Audit Committees. Washington, DC: SEC.

Securities and Exchange Commission. (2003b). Release Nos. 34-48745. NASD and NYSE rulemaking. Relating to Corporate Governance. Washington, DC: SEC.

Singh, V., Vinnicombe, S., \& Johnson, P. (2001). Women directors on top UK boards. Corporate Governance: An International Review, 9(3), 206-216.

Sun, J., Lan, G., \& Liu, G. (2011). Independent Audit Committee Characteristics and REM: Evidence after the Sarbanes-Oxley Act. Retrieved November 23, 2013, from http://aaahq.org/AM2011/abstract.cfm?submissionID=734

Sun, J., Lan, G., \& Liu, G. (2014). Independent audit committee characteristics and REM. Managerial Auditing Journal, 29(2), 153-172.

Thiruvadi, S. (2012). Gender differences and audit committee diligence. Gender in Management: An International Journal, 27(6), 366-379.

Thiruvadi, S., \& Huang, H.W. (2011). Audit committee gender differences and earnings management. Gender in Management: An International Journal, 26(7), 483-498.

U.S. House of Representatives. (2002). The Sarbanes-Oxley Act of 2002. Public Law 107-204 [H. R. 3763]. Washington, D.C.: Government Printing Office.

Visvanathan, G. (2008). Corporate governance and REM. Academy of Accounting and Financial Studies Journal, 12(1), 9.

White, M.J. (2014, June 23). A few things directors should know about the SEC. Remarks delivered at the Stanford University Rock Center for Corporate Governance 20th Annual Stanford Directors' College, Stanford, CA. Retrieved from http://www.sec.gov/News/Speech/Detail/Speech/1370542148863\#.VOn0gHw8DYK

Zang, A.Y. (2011). Evidence on the trade-off between real activities manipulation and accrual-based earnings management. Accounting Review, 87(2), 675-703. 